\title{
PROFESSORAS VIRTUOSAS; MÃES EDUCADAS: RETRATOS DE MULHERES NOS TEMPOS DA REPÚBLICA BRASILEIRA (SÉCULOS XIX/XX)
}

\author{
Jane Soares de Almeida \\ Universidade de Sorocaba (UNISO) \\ janesoaresdealmeida@uol.com.br
}

\section{RESUMO}

Nos tempos republicanos, o Brasil intentava consolidar-se como país independente e democrático. Apesar das ideias liberais e do surto progressista, os expoentes intelectuais republicanos ainda se apegavam aos valores morais de fundo religioso na ordenação social, o que indubitavelmente também acontecia em quase todo o território nacional nos centros mais desenvolvidos. Dentre esses valores, a educação feminina e o papel das mulheres como sustentáculo da família e da Pátria, eram ressaltados. O discurso da época enfatizava a necessidade de educação para as mulheres como pano de fundo para a educação dos homens e o desenvolvimento do País. O magistério exercido por mulheres era destacado no discurso oficial como forma de elevação moral. Os cânones educacionais vigentes erigiam uma figura feminina espelhada na religião católica, na qual a maternidade era um dos mais sagrados valores. A sociedade acatava os fins de sua educação e do seu trabalho no magistério, como um prolongamento da missão materna. Isso, entre outros fatores, contribuiu para a feminização da profissão e criou uma imagética social acerca das mulheres que ainda persiste nos tempos atuais.

Palavras-chave: mulheres, religião, educação feminina, magistério.

\section{VIRTUOUS TEACHERS; EDUCATE MOTHERS: PORTRAITS OF WOMEN IN THE BRAZILIAN REPUBLIC TIMES (XIX/XX CENTURIES)}

\begin{abstract}
:
In Republican times, Brazil was attempting to consolidate itself as an independent, democratic country. Despite the surge of liberal ideas, the progressive republican intellectuals still clung to the moral values of religious background in the social order, which undoubtedly was also the case in almost all the national territory in the more developed centers. Among these values, were emphasized female education and the role of women as the mainstay of family and homeland. The discourse of the time highlighted the need for education for women as a backdrop for the education of men and the development of the country. In official discourse, teaching exercised by women appeared as a form of moral elevation. The current educational canons erected a female figure mirrored in the Catholic religion, in which motherhood was one of the most sacred values. The society accepted the purposes of their education and their work in teaching, as an extension of the maternal role. This, among other factors, contributed to the feminization of the profession and created a social imagery about women that still persists in modern times.
\end{abstract}

Keywords: women, religion, female education, teaching 


\section{Introdução}

Abordar a temática da educação das mulheres no Brasil entre o século XIX e primeiras décadas do século XX implica necessariamente em realizar uma reflexão sobre as questões culturais modeladas pela religiosidade. No caso brasileiro, a Igreja Católica teve influência fortemente marcada pelas normas e restrições dirigidas ao sexo feminino, na defesa da sacralidade do casamento e de uma educação destinada às futuras esposas e mães. As principais destinatárias da ideologia católica eram as mulheres, consideradas indispensáveis no fortalecimento do lar cristão. Recaíam sobre elas as injunções da moralidade e religiosidade. As que se enquadravam nessas normas eram consideradas honestas, as demais eram as transgressoras, que deveriam sofrer a rejeição social e serem marcadas pelo estigma do pecado. Esse estigma recaía prioritariamente na sexualidade, feminina, campo no qual o catolicismo foi extremamente conservador; quanto aos homens havia maior permissividade.

Numa visão panorâmica sobre o papel da religião católica na formação das almas e no imaginário do povo brasileiro, torna-se importante ressaltar alguns de seus aspectos no campo do sagrado para um melhor entendimento de sua relação com a imagética social acerca das mulheres. Primeiramente, há que se considerar que a religião, seja qual for a crença adotada, ocupa lugar determinante na vida humana e insere-se na cultura de um povo ao incorporar o delineamento das identidades sociais e políticas; em nome das religiões guerras foram travadas e civilizações dizimadas. O Cristianismo é uma das religiões que mais produziram santos na crônica do martirológio da Humanidade. ${ }^{1}$ Jesus é a figura que ocupa uma posição central no Cristianismo e a cruz na qual morreu tornou-se uma representação universal da fé cristã, numa linguagem simbólica da dívida dos homens para com Deus. Sua mãe, a Virgem Maria, se tornou o emblema da santidade e da pureza, qualidades que deveriam possuir as mulheres para o desempenho da sublime missão da maternidade, imagética veementemente defendida pelos católicos e por amplos setores sociais.

A Igreja que se construiu tomando por base os ensinamentos cristãos é um local que se convencionou denominar como uma casa de orações ou um local de cultos. A Igreja Católica, nos seus primórdios, se constituiu essencialmente como uma seita de judeus, foi cruelmente atacada e se firmou sobre o sangue de seus mártires, desde os primeiros cristãos perseguidos pelos romanos. Para sobreviver teve de se adaptar repetidas vezes, sofreu cismas e rupturas ao longo dos séculos, até ser finalmente denominada Católica, ou seja, universal, palavra usada para denotar uma única corrente separada das demais. Sua virada maior e decisiva ocorreu com a conversão do Imperador Constantino no ano 312; a partir daí quase todos os romanos foram mais cristãos do que pagãos. De minoria perseguida passou a maioria dominante e assim nasceu a Cristandade na Europa. (LANE, 1996, p. 354). No século XVI, com a Reforma Protestante, a Igreja Católica Romana se enfraqueceu. Apesar de no início os reformadores terem lutado juntos, logo se dividiram em dois grupos adversários: os luteranos e os reformados. Posteriormente, houve maiores fragmentações e o Protestantismo adotou diversas denominações e orientações litúrgicas como a Igreja Anglicana/Episcopal, a Luterana, a Reformada/Presbiteriana e as Igrejas Livres que assumiram várias denominações como Batistas, Metodistas, Movimento Ecumênico, mantendo, porém, em comum, a devoção a Cristo. Desde o início os protestantes se viram como uma redefinição da Igreja que evoluiu a partir dos ensinamentos dos apóstolos. Existe uma diferença entre católicos e protestantes em relação à visão dos indivíduos no seio da Igreja: enquanto a católica considera que estes vêm 
depois da Igreja, os protestantes os colocam antes e esta é vista como agregadora daqueles que acreditam na fé e a professam (SADGROVE, 1996, p.380).

Os cristãos, ao longo dos séculos, impuseram sua crença ocidental aos demais povos ao redor do mundo, por meio de uma cultura revestida daquilo que alguns estudiosos classificam como imperialismo teológico e cultural, num processo de aculturação que levou à perda da religião original de conglomerados primitivos. Nesse processo, as igrejas, católicas ou protestantes, também deram significativa contribuição na luta pelos povos oprimidos, na erradicação da pobreza e da fome, na defesa da justiça e da paz como utopias possíveis para a Humanidade. As igrejas ainda se representam como moralizadoras e guardiãs da ética sexual e da sacralidade do casamento, além de incumbidas de facilitar a passagem das almas para a vida eterna. $\mathrm{Na}$ transmissão cultural pela via educativa, proporcionada pela organização de uma sociedade, as religiões, historicamente, imprimiram sua marca e seus dogmas, colaboraram para esculpir mentalidades, ordenaram comportamentos e promoveram mudanças concretas nos vários agrupamentos humanos. Para Lane (1996, p. 392),

(...) as crenças religiosas são toleradas no Ocidente como opiniões pessoais ou como aspectos culturais. Nas escolas, as crianças são estimuladas a aceitar a religião (se elas forem ocidentais) como um sistema de valores pessoal ou, (se elas não forem etnicamente ocidentais) como um aspecto de sua cultura.

No catolicismo, desde sua gênese, fundamentada no Cristianismo, as igrejas colaboraram para esculpir mentalidades, ordenaram comportamentos e promoveram mudanças concretas nos vários agrupamentos humanos. Apesar dos seres humanos terem uma natureza em comum, sua história, sociedade, cultura, religião são diferentes e esses fatores apresentam multiplicidade de aspectos, crenças, costumes, valores, hábitos, enfim tudo aquilo que se convencionou denominar pluralismo; junto às crenças de uma determinada cultura, se imbricam as ideologias, os pontos de vista morais e os fatos significativos da realidade. A estes se aliam questões de natureza subjetiva, derivadas da necessidade muito humana de crer no divino, para subjugar o medo atávico da morte, talvez a única certeza no âmbito das ações de homens e mulheres. Isso, de certa forma, pode também ser declarado como uma busca pela Verdade, outra utopia suprema, ao lado da Igualdade, Justiça e Paz. Podemos considerar que nos tempos pós-modernos, os indivíduos não mais definem sua identidade pela religião, com as exceções dos locais onde ainda permanecem conflitos de origem religiosa.

Para Souza, (2007, p. 19):

Historicamente, as religiões não têm protagonizado mudanças sociais no que se refere à superação da noção de subordinação feminina. Ao contrário, frequentemente têm reforçado representações domesticadoras, traduzindo o ser mulher como ser virtuosa, o que implica dizer ser uma boa mãe, ser uma boa esposa, ser uma boa dona de casa, ser uma serva fiel na religião etc. Ser boa mãe, esposa, dona de casa e fiel religiosa implica reproduzir as normas já objetivadas que reservam às mulheres alguns atributos: fragilidade, submissão, cuidado (com filhos, marido e atividades domésticas) etc. A exclusividade da religião no contexto familiar perdurou por séculos. A casa, lugar intocável pelo Estado e pela sociedade circundante, deixou-se tocar pela religião, que durante anos a fio conseguiu uma ascendência sobre o lar que nenhuma outra instituição social alcançou, além da própria instituição familiar. 


\section{Homens, mulheres e religião: alguns paradoxos}

A dupla moral sexual que concedia direitos aos homens e deveres para as mulheres, entre eles a exigência de fidelidade absoluta, já havia sido questionada no século XVII pelas inglesas e no século XIX pelas feministas do International Council of Women que se reuniu em Washington em 1888. (ALMEIDA, 2007). Essas mulheres, ao defenderem os direitos femininos, não deixavam de considerar o matrimônio como seu destino inato e a sua conseqüência, a maternidade, como suprema aspiração. Portanto, apesar do seu desejo de liberdade, a vontade de cumprirem a destinação materna, versão engendrada pela ideologia e pela educação, as condenava a uma servidão permanente por se dissociar o ato de ser mãe da realização pessoal por outras vias que não essa.

Talvez as perguntas que pairem perante o arrazoado acima sejam: em tudo isso, onde se insere a questão religiosa, articulada à educação, ambas como formadoras de identidades e unificadoras de comportamentos? Como lidar com essas questões num mundo onde a fé parece ter perdido posição em favor da ascensão social, do lucro e do capital e os objetivos educacionais apresentam sérios obstáculos à sua consecução? Provavelmente, não no mundo pós-moderno onde os maiores fervores religiosos também se digladiam com a sede de riqueza e poder; um mundo onde a educação ainda não se universalizou, mesmo tendo se democratizado. Porém, nos séculos XIX e boa parte do século XX, tanto a educação, como a religião, foram marcos fundamentais sobre os quais se assentavam as aspirações, os costumes, as tradições, a política, a cultura, a vida social e a economia. Sob suas sombras se modelavam as identidades, os comportamentos, hábitos e costumes e se normatizava a vida social e a sexualidade. Transgredir as normas religiosas era romper com as regras da sociedade, da política e da economia; não ter acesso à educação era estar à margem do sistema. Aí, possivelmente, estejam as diferenças fundamentais entre religião e educação: enquanto a primeira buscava conseguir maior número de adeptos; a segunda ficou restrita a poucos. Embora pobres, negros, indígenas, escravos, mulheres e meninas fossem à igreja, estes nem sempre podiam ir à escola, inclusive às que funcionavam sob o beneplácito e a organização da Igreja. Com o advento das idéias liberais e positivistas veiculadas pelos ilustrados antes e depois da República, o panorama social do Brasil se transformou. A educação fez parte integrante do projeto civilizador republicano e o poder da religião católica foi ameaçado com sua separação do Estado, agora laico, juntamente com a relativização de sua influência no campo escolar, num processo que havia se estruturado desde o Segundo Império. Esse poder também foi parcialmente ameaçado com a inserção do protestantismo que trouxe ao País, a partir da segunda metade do século XIX, um novo sentido ético-religioso com notável cunho político, evidenciado naquilo a que Max Weber definiu como a ética protestante e o espírito do capitalismo.

O patriarcado brasileiro, fortemente imbuído pela cultura francesa, teve no meio rural, a figura dos padres e capelães de engenho como agentes mantenedores da cultura luso-cristã. Posteriormente, houve a influência de pastores protestantes, que se radicaram nas cidades e vilas e se embrenharam pelos sertões, ao encontro de uma população da região do açúcar que estava aberta para as ideias religiosas trazidas do seu país de origem. No meio urbano, o alto clero e as oligarquias se aliaram à nova classe burguesa que se firmava nos finais dos mil e oitocentos e teve continuidade nos mil e novecentos, para impor seus valores no cenário nacional. E tanto no campo como na cidade, as mulheres foram as principais destinatárias da 
ideologia religiosa, as fiéis mantenedoras da ordem, da moral e dos preceitos cristãos. Nisso católicos e protestantes não se distinguiram, apesar das diferenças ideológicas entre si. $\mathrm{O}$ discurso médico sanitarista, no século XIX impôs a ideologia do amor materno, plenamente apoiado pela Igreja católica, ao representar as mulheres como as guardiãs do lar cristão. Seu papel como educadoras da infância no recesso do lar, preparou o terreno para sua inserção socialmente aceita como professoras nas escolas, ação impulsionada pelo ideário republicano e o governo estatal. Eram as mulheres as depositárias das esperanças da raça e as responsáveis em formar e educar os futuros cidadãos. Essa ideologia construiu um discurso exaltado e ambivalente, que visava moldar a figura feminina:

(...) de um lado, expunham-se as recompensas da carreira do casamento e da maternidade: uma relação mais sólida entre os membros da família, o amor do marido, a mulher elevada à condição de figura central do seu território. De outro, as punições: sentimento de culpa, frustração, os castigos da natureza contrariada, os perigos físicos da não-procriação ou da retenção do leite, no caso das mães, etc. (RAGO, 1987, p.80).

Do princípio até a metade do século $\mathrm{XX}$, as expectativas sobre a conduta feminina, as doutrinações religiosas impostas pela Igreja Católica, as implicações na sexualidade, o controle da feminilidade e as normatizações sociais, aliadas às exigências de casamento religioso, o batismo dos filhos e a confissão dos pecados, também significavam uma exacerbada vigilância do corpo e da alma das mulheres. Acreditava-se que a liberação econômica para as mulheres, representada pelo desempenho do trabalho remunerado, e seu desenvolvimento intelectual, dado por uma educação não diferenciada da masculina, significavam a ruptura com os acordos tacitamente estabelecidos, ocasionando desordem social ao alijar do sexo feminino a subordinação ao modelo androcêntrico vigente. Era necessário que as mulheres fossem educadas para que o lar, marido e filhos com isso se beneficiassem. Essa ideologia defendia que, mantida dentro dos limites sociais e organizada para atender a essas prioridades, a instrução feminina não ameaçava os lares, a família, o homem. Nisso concordavam católicos, protestantes, positivistas, republicanos, liberais, conservadores; enfim toda a sociedade, incluindo as próprias mulheres. A educação que, a princípio, foi negada sob o pretexto de que demasiados conhecimentos seriam inúteis, até mesmo prejudiciais à frágil constituição física e intelectual feminina, posteriormente, se revelou como algo desejado, quando as mulheres passaram a ser vistas como as principais responsáveis pela moralização da família e da Pátria, com a divulgação do projeto liberal republicano para a educação. A necessidade de instrução e educação constituiu motivos de reivindicações para algumas mulheres envolvidas com as idéias veiculadas pelo feminismo mundial, como forma de alterarem um destino imposto pela sociedade cerceadora e moralizadora da época. Porém, assim que ficou ao seu alcance, essa educação foi vigiada e regulamentada pelo poder público e demais setores sociais. Nas escolas, o ensino oferecido evidenciava a subordinação feminina aos mesmos cânones educativos e religiosos voltados para a domesticidade o que era revelador do que delas se esperava para exercerem as funções voltadas para as demandas da sociedade urbanizada que definia um perfil idealizado de homens e mulheres para inserir o País entre as nações em desenvolvimento, conforme haviam pregado os liberais republicanos.

Nos anos iniciais do século XX, a possibilidade de se profissionalizarem no magistério primário significou um meio das mulheres poderem vislumbrar uma chance de sustento, sem a obrigação do casamento ou a humilhação de viver da caridade alheia. Como o cuidado com 
crianças não fugia da maternidade e da domesticidade, as mulheres, como professoras, poderiam continuar desempenhando sua missão, nos moldes propostos pela sociedade. Um meio social que concordava com a relevância da educação feminina para atender aos apelos e interesses da nação por meio de famílias solidamente estruturadas e por considerá-las indispensáveis na educação dos homens, pela via do cuidado materno. Para as mulheres, educarem-se e instruírem-se, mais do que nunca, foi uma forma de quebrarem os grilhões domésticos e conquistarem uma reduzida parcela do espaço público. Foi também a possibilidade de se adequarem às normas sociais, ao mundo novo que se descortinava e principiava a selecionar os mais preparados intelectualmente e abria cada vez maior espaço para a sociabilidade. Possuidoras dos saberes domésticos e dos saberes privados sobre o mundo dos homens, as mulheres aspiravam pelo saber público, embora derivado do saber masculino e referendado com seu selo oficial. Esse saber público era, de certa maneira, uma possibilidade de acesso ao poder, ainda que restrito, mas significava também o repúdio a um sistema de desigualdade e de opressão, assim como a oportunidade de confrontarem esses mecanismos pela via de maiores conhecimentos intelectuais. Entretanto, é notório, do ponto de vista histórico, que a educação e a profissionalização femininas no Brasil, assim como aconteceu em outros países, respeitando-se alguns avanços, sempre foram relegadas a plano secundário. As reivindicações das mulheres por mais instrução costumavam ser objeto de distorções da parte dos homens e até das próprias mulheres, que acatavam a destinação de serem confinadas à reprodução biológica e à vida no mundo privado. Esse fato implicava no estabelecimento de relações de poder, próprias das relações de gênero, as quais passavam, inclusive, pela questão do saber, pois conhecimento e poder sempre estiveram necessariamente interligados, dado que manter o dominado longe do saber foi e continua sendo uma estratégia eficiente no controle e na manutenção dos mecanismos de dominação. Situa-se aí a ambigüidade da posição feminina a respeito do trabalho e da instrução, representada pelo equilíbrio entre a condição desejável e a possível de se obter, instaurando entre esses dois extremos, a hermenêutica da sua condição.

No período referido, as expectativas sociais sobre a conduta feminina se traduziam por uma exacerbada vigilância do corpo (e da alma) das mulheres, inclusive nos limites urbanos que impuseram similares costumes próprios do meio rural e mantiveram os mesmos hábitos severos dos tempos coloniais. Guardadas zelosamente por pais, irmãos e maridos, não poderiam, a não ser pela educação, terem condições de comandar suas vidas e inserirem-se no espaço público. O magistério, pela sua especificidade, representada pelo cuidado de outrem foi, talvez, uma das maiores oportunidades para se atingir esse equilíbrio, por ser uma profissão considerada adequada às mulheres, no desempenho do papel de regeneradoras da sociedade e salvadoras da pátria, além de ser aceitável, em termos sociais, trabalharem como professoras. No contexto urbano das regiões mais povoadas, nos anos que precederam a proclamação, a iluminação a gás, os carros de boi, a primeira linha de bonde, algumas casas comerciais, significavam pequenos lustros de progresso, num ambiente de higiene precária, promíscuo e de pouco lazer. No interior, com a população fortemente concentrada na zona rural, as vilas e povoados careciam de quaisquer benfeitorias e a criação de classes para meninos e meninas obedecia a regras de pouca oferta e baixa procura. As crianças aprendiam no lar, com os pais, se estes eram alfabetizados; poucos podiam pagar professores/as particulares para suas filhas, que ficavam ausentes de qualquer instrução elementar. A distância da casa à escola era outro sério obstáculo para a família que desejava que seus filhos ou filhas estudassem. Nesse meio intelectualmente pobre, a escola não se colocava como 
prioridade e abriam-se classes de duração efêmera, para aqueles que podiam arcar com os custos da educação, já que a maioria pertencia à iniciativa particular. ${ }^{2} \mathrm{O}$ governo oferecia $\mathrm{O}$ ensino elementar nas escolas mistas, com aulas regidas por professoras, onde não fosse possível criar classes para ambos os sexos; orientava a criação e o funcionamento do ensino num cenário no qual o pensamento educacional republicano, aberto à livre iniciativa, comungava com as propostas de coexistência de instituições públicas e privadas. Porém, as escolas mistas eram freqüentadas apenas por meninas dos extratos sociais desfavorecidos e, mesmo assim, os pais logo as retiravam das escolas assim que aprendiam os rudimentos da leitura e escrita, o que fazia com que se fechassem classes por baixo comparecimento de alunas. ${ }^{3}$ Do século XIX até a primeira metade do século XX, as moças eram educadas para a submissão e a dependência dos homens do ponto de vista intelectual e financeiro, sendo encorajadas a desenvolverem a religiosidade, as virtudes, o espírito de sacrifício, a pureza, princípios aprovados pela Igreja Católica. O repúdio em educar juntos meninas e meninos tinha por base uma razão cultural representada por uma sociedade que se erigia em valores coloniais luso-cristãos, nos quais a instrução feminina era dispensável. Quando, por questões de economia, se instituíam classes mistas, inclusive nas escolas normais, havia pressões ideológicas para a organização curricular, exigindo-se temas específicos para as meninas, como corte e costura, bordado e culinária, as ditas prendas domésticas, o que resultava em currículos distintos para um mesmo grupo de alunos; com horários de entrada, saída e recreio diferentes e até mesmo divisões físicas nas salas de aula, mantendo-se assim uma separação desejável para atender as exigências dos pais, professores e governantes.

A chegada dos protestantes nas décadas finais do século XIX e a criação das pequenas escolas ao lado das igrejas e de colégios, nas localidades maiores, propiciou uma concretização do que já acontecia nos Estados Unidos acerca da educação para ambos os sexos. Os missionários norte-americanos, em que se considerem as ideias democráticas e libertárias de que estavam imbuídos, também eram movidos pelas mesmas medidas de economia de investimentos físicos e recursos humanos, porém tinham um discurso ideológico compatível com as lutas feministas que se processavam no seu país, acerca de igualdade de oportunidades educacionais para os dois sexos. As mulheres passaram a considerar as classes mistas como a chance de oferecer às meninas a mesma educação que aos meninos, fornecendo a estas maiores oportunidades educacionais e a possibilidade de poderem exercer uma profissão, o que lhes traria mais liberdade individual. Argumentavam que, com a educação, homens e mulheres poderiam viver mais harmoniosamente indo em direção ao futuro social da convivência entre os sexos e estender suas concepções para além dos muros escolares em busca de uma verdadeira igualdade. As mulheres, notadamente aquelas que puderam ter a oportunidade de obter uma educação esmerada, embora tradicional e de acordo com os paradigmas sociais vigentes, foram as grandes defensoras de se estender a escolaridade ao sexo feminino além daquela ministrada no recesso do lar. Excluídas da escolaridade ao longo da História por estarem impedidas de freqüentar as escolas, (na maioria, destinadas aos meninos e rapazes), as mulheres do final do século XIX e princípios do século XX engajaramse nas lutas por maiores direitos educacionais. As líderes feministas do período consideravam que a melhor forma para se alcançar a igualdade era por uma educação igual para os dois sexos a partir do seio familiar e meio social, o que seria concretizado na escola.

No caso das mulheres brasileiras, a cultura portuguesa foi determinante para esculpir na sociedade brasileira os contornos definidos para o desempenho dos papéis sexuais, e eficiente em construir uma imagética social, na qual o espaço feminino por excelência era o 
recesso do lar. Para a nação lusitana, tradicional e conservadora, a responsabilidade feminina nunca deveria transpor as fronteiras do lar, nem ser objeto de trabalho assalariado. A independência econômica das mulheres, obtida pelo desempenho de uma profissão e sua autonomia intelectual representada por uma educação igual à dos homens, significava a ruptura com acordos estabelecidos desde outros tempos e poderia ocasionar desordem social. A população seguia as regras ditadas pelas elites, aprofundando o fosso que separava homens e mulheres. Essa ideologia se manteve na Colônia e no Império; nos tempos republicanos os discursos positivista e eugênico passaram a veicular a necessidade da educação feminina como forma de se manter a família e a Pátria dentro de cânones desejáveis para o desenvolvimento. Os higienistas já haviam plantado a semente das mulheres serem as principais responsáveis pela saúde de seu corpo e dos filhos; os homens deviam ser os provedores da família, os guardiões das mulheres. A educação seguiu os mesmos objetivos definidos quanto aos papéis sexuais: às mulheres, a reprodução; aos homens, a proteção. Esses valores se estenderam a todas as áreas: no lar, na política, na economia, na sociabilidade, na religiosidade, nos hábitos, costumes, enfim, na própria cultura do período e instalaram uma imagética resistente a mudanças nos diversos setores sociais.

Dos finais do século XIX até a metade do século XX, a vida em sociedade, as expectativas sobre os papéis sexuais, as doutrinações da Igreja católica, as implicações na sexualidade, o controle dos corpos e da mente, a inculcação moral, mostravam um país preocupado em construir uma sociedade que deveria se expandir sem perder valores tradicionais. As mulheres eram as principais destinatárias de uma ideologia que se centrava na vigilância e na profecia de destinos para cada sexo: ao homem, o espaço público, a política, a gerência de recursos, a liberdade; para a mulher, o espaço privado, a dependência financeira e emocional, a castidade. Nesse contexto, mesmo a educação na mais tenra idade devia ser normatizada para não pôr em risco o desempenho dos papéis reservados a cada sexo. Conscientes dos receios da sociedade de que a mulher educada abandonasse a sagrada missão a ela confiada, a de dar filhos fortes para a Nação, e que isso interferisse na sua saúde e na da prole, mesmo as pioneiras feministas compartilhavam com os homens o ideal de manter a mulher no espaço que lhe foi reservado: o mundo da casa. Durante todo o tempo o discurso social caracterizou-se dentro dos princípios da ideologia masculina, numa sociedade que se assumia androcêntrica, orientada no plano da religiosidade pelo catolicismo. Os movimentos feministas que se iniciaram desde os finais dos mil e oitocentos abalaram, parcialmente, a visão colinial da educação das mulheres contaminar sua consciência e comprometer a sanidade de seu corpo e de sua alma. A saída para romper com os mecanismos que aprisionavam as mulheres no determinismo dos papéis sexuais seria uma educação qualitativamente igual à dos homens de forma a compartilharem os mesmos espaços, iguais professores e conteúdos, apesar de não negarem que as noções essenciais para a domesticidade deveriam continuar a ser transmitidas na educação familiar.

No Brasil, o regime republicano instituiu o Código Civil em 1916, no qual os homens chefiavam a família, administravam os bens, e autorizavam o estudo e o trabalho feminino. $\mathrm{O}$ amparo legal era o que menos pesava nos comportamentos derivados das tradições imutáveis, desde os tempos da Colônia, que colocavam os homens no centro do universo social e doméstico. O processo de urbanização promoveu alterações na posição social feminina, mas o domínio masculino continuou determinante na organização vigente. Isso porque, apesar de ser considerada superior, do ponto de vista moral, era natural que as mulheres ocupassem um lugar inferior na escala social, por conta das diferenças entre os sexos e que os homens 
detivessem as rédeas do poder. Na organização das escolas, essa ideologia, não atingiu uniformemente toda a população, pois a separação dos sexos e uma instrução desigual demonstravam uma discriminação de gênero que repercutia na esfera social. A cultura lusitana deixou raízes na sociedade brasileira na definição dos papéis sexuais e em limitar a responsabilidade feminina às fronteiras domésticas; as idéias progressistas e libertárias dos protestantes norte-americanos, comungadas pelos republicanos não conseguiram romper com esse padrão. A complexidade inserida nos debates coeducativos fez com que essa discussão não ultrapassasse o espaço da instituição escolar - as propostas eram republicanas e, por conseqüência, de cunho liberal - e a intolerância religiosa com as teses do liberalismo colocaram educação igual para meninos e meninas, e religião católica, como antípodas. Até a metade do século XX, a militância católica impôs sua vontade no cenário social e educacional. Se no século XIX havia na cultura brasileira alguns sinais favoráveis à disseminação dos ideais protestantes, divulgados como uma alternativa ao catolicismo, em relação ao sexo feminino não houve avanços significativos. Não se pode esquecer que a modéstia de recursos das Igrejas protestantes dos Estados Unidos fez com que os missionários compartilhassem os mesmos problemas de verbas das escolas brasileiras. No país de origem dos missionários, a ideologia de delimitar espaços para cada sexo também era uma realidade. Com a ofensiva católica, na primeira metade do século XX, muitas escolas protestantes fecharam suas portas e a proposta de se estender uma educação igual para os dois sexos limitou-se a colocá-los em classes onde assistiam aulas juntos, com os mesmos professores, os mesmos métodos, sob a mesma direção. Quanto à projeção da futura vida social para cada sexo, não havia discordância entre católicos e protestantes. Fora da escola tudo permaneceu como antes: o homem mandava, a mulher obedecia. O homem cuidava, a mulher pertencia. Mediando essa relação, a educação escolar prosseguiria como uma forma de controle social e controle de gênero, mesmo ao embutir em seu discurso a perspectiva da igualdade, da liberdade e da cidadania. Num país que durante décadas acreditou na superioridade masculina sobre a feminina, não seria assim tão fácil romper com essa pretensa supremacia.

\section{Magistério feminino: a conservação dos valores tradicionais}

$\mathrm{O}$ acesso à educação e a possibilidade aberta às mulheres de exercerem uma profissão, representada pelo ensino de crianças de tenra idade, revelaram-se como espaços para a continuidade da opressão de gênero. À medida que a educação das mulheres possibilitou conservar nos lares, nas escolas e na sociedade, a hegemonia masculina, se instaurou um paradoxo: detentores do poder econômico e político, os homens apropriaram-se do controle educacional e passaram a ditar as regras e limites da instrução feminina e controlar seu ingresso nas profissões que poderiam desempenhar. No ensino secundário elaboraram leis e decretos, criaram escolas e liceus, compuseram seus currículos e programas, escreveram a maioria dos livros didáticos e manuais escolares, habilitaram-se para a cátedra das disciplinas consideradas nobres e segregaram as professoras a espaços femininos como Economia Doméstica, Música, Puericultura, Culinária, Etiqueta e similares. As mulheres se encarregaram das salas de aula e do cuidado com crianças pequenas, mantendo-se a mesma ordem vigente no arcabouço social e familiar; disciplinada pelos homens, a educação das mulheres continuou um prolongamento da educação familiar, com o respaldo e bênção da Igreja Católica. O estudo para as moças configurava-se como uma preparação para o que realmente importava em suas vidas: casar e ter filhos. Essas mulheres, de acordo com o 
imaginário que se forjou nos tempos pós-republicanos, não eram mais as procriadoras incultas, mas as futuras esposas educadas, conhecedoras das necessidades do marido e dos filhos, alicerces da moral e dos bons costumes, religiosas e fiéis guardiãs do lar cristão e patriótico. Romper com tais estruturas, e havia quem o fizesse, significava condenação social. As mulheres de classe elevada sempre se garantiam financeiramente se possuíssem fortuna familiar, ou pela via de um casamento vantajoso. Serem belas, cultas, virtuosas e educadas eram os atributos indispensáveis para um bom casamento, porém não tinham direito à herança e seus bens de herança passavam automaticamente às mãos do marido quando do enlace matrimonial; portanto, não é de se espantar o desejo de filhos homens nas famílias de posses. No outro extremo, havia aquelas que, sem possibilidades de casarem tinham que depender da boa vontade de parentes e amigos, ou resignarem-se ao papel de governantas em casas ricas. Ou ainda, serem as eternas tias no cuidado dos filhos de irmãos ou irmãs. Para essas mulheres, com o movimento da ampliação do ensino e o crescimento das escolas normais após a República, o magistério apareceu como uma alternativa possível de lhes dar independência e subsistência no desempenho de um trabalho digno. A oportunidade de ampliar seus estudos nas escolas normais, que se qualificavam como centros irradiadores de ensino abertos às jovens atraiu um número significativo de moças desejosas de obter um diploma. Ser professora para atuar num ambiente escasso de oportunidades educacionais se revelou como uma aspiração feminina, mesmo que não fosse para exercer a profissão, pois, muitas vezes, a maternidade e o desempenho profissional eram incompatíveis no cotidiano feminino da época.

\section{Ser professora: prolongamento da missão materna}

A feminização do magistério no Brasil ocorreu num momento em que o campo educacional se expandiu e a mão-de-obra feminina principiou a revelar-se necessária, tendo em vista, entre outras causas, os impedimentos morais dos professores educarem as meninas e a recusa à coeducação dos sexos, liderada pelo catolicismo conservador. Essa possibilidade de profissionalização produziu uma grande demanda pelo magistério, aliada à expansão das escolas normais pelo interior das províncias e caminhou paralelamente ao discurso ideológico que alocava às mulheres um melhor desempenho no ensino de crianças. Nesse contexto, o magistério primário, como ocupação essencialmente feminina, propiciou às mulheres, notadamente da classe média que se alicerçava no panorama sócio-econômico do país, a principal oportunidade para ingressarem no mercado de trabalho. A possibilidade de exercerem uma profissão revestida de dignidade e prestígio social fez com que o magistério se tornasse extremamente popular entre as jovens da classe média. Se, a princípio, a sociedade temia as mulheres instruídas, agora tal instrução passava a ser desejável, desde que não oferecesse riscos sociais. A concepção sobre a educação feminina começou a dar sinais de mudança quando as necessidades da classe média e a situação do Brasil nas duas primeiras décadas do século XX principiaram a dar indícios de transformações. Esses indícios demonstravam uma intencionalidade de dar ocupação profissional às jovens na nova sociedade que se alicerçava no quadro econômico do País. Portanto, a educação feminina veio para atender aos apelos e aos interesses da Nação e para as mulheres, a educação escolar, mais do que nunca, significou uma forma de quebrar os grilhões domésticos e conquistar uma reduzida parcela do espaço público. Foi também a possibilidade de se adequarem às normas sociais e ao mundo novo que se descortinava; um mundo hierarquizado e organizado de acordo com as 
normas definidas por uma sociedade que, ao começar a selecionar os mais preparados intelectualmente, abria maior espaço para o protagonismo social no ambiente urbanizado.

\section{Algumas considerações; na História não há conclusão}

A inclusão da categoria religião, como parte da cultura, para analisar as relações entre os sexos e o papel das mulheres no edifício social revela um importante aporte teórico para as possibilidades investigativas nos estudos de gênero por representar o ponto nevrálgico para onde convergem as relações de poder, estabelecidas no nível simbólico e no imaginário, ao aglutinarem a essencialidade da existência humana. A crença no mundo sobrenatural, o controle da sexualidade, os arquétipos religiosos ditando normas de pureza e mansidão, normatizavam o comportamento social, com maior ênfase no sexo feminino. A Igreja católica exerceu forte influência nesse campo, ao ditar regras sociais, morais e de comportamento religioso pela via do ensino. Ao centralizar sua atenção nas elites deixava o povo às margens das instituições, (afastado da escola, unido pelo concubinato sem regularizar sua união, batizar os filhos e enterrar os mortos), ausente das bênçãos dos clérigos e da sacralização dos costumes. Estes costumes eram definidos pela instituição religiosa incumbida de perpetuar a tradição luso-cristã, na qual normas consideradas desviantes e hábitos em desacordo com a moral eram severamente punidos por conta do conceito de pecado, com a conseqüente e medieval ameaça da excomunhão e do inferno.

O adestramento dos corpos, capitaneado pela Igreja católica, possuía como alvo principal a sexualidade feminina. Essa sexualidade, ao ultrapassar o permitido pela sociedade e pelas regras religiosas, ameaçaria o equilíbrio da família e do grupo social. Por carregar a nódoa do pecado original, a mulher deveria ser vigiada, mesmo que isso significasse tolher sua liberdade, abafar sua individualidade e privá-la do livre arbítrio. O casamento e a maternidade eram a salvação feminina; honesta era a esposa mãe de família; desonrada era a mulher transgressora que desse livre curso à sexualidade ou tivesse comportamentos em desacordo com a moral cristã. Para a missão materna as meninas deveriam ser preparadas desde a mais tenra idade, fosse nos colégios católicos, nas escolas protestantes ou nas instituições públicas. As meninas tornavam-se esposas e mães honradas, (criadas na casa dos pais e com um destino profetizado), casavam-se na igreja, vestidas de branco para demonstrar a virgindade. Uma virgindade que depois se revestiria da missão sagrada de serem mães, num paradoxo insolúvel que não resolvia o teorema da maternidade e a necessidade do intercurso sexual para sua consecução. Na visão da sociedade, a maternidade era o ápice na vida de toda mulher. Pela religião (e, certamente, pela educação), ela se afastava de Eva e aproximava-se de Maria, a mulher que pariu virgem o menino Jesus, o qual teria como missão ser o salvador do mundo. Esse comportamento social não significava uma atitude de misoginia, era antes uma crença num mundo onde cada coisa em seu lugar garantiria a Ordem e o Progresso. Neste mundo, as alteridades se moviam como placas tectônicas; sobrepostas e sem permeabilidade quando se tratava das relações de gênero.

A religiosidade se revestia de caráter disciplinador; ancorada no sagrado atuava como normatizadora da consciência; estabelecia conexões com vários aspectos da prática social como a vida cotidiana, a fé, a economia, a política, a festa, os rituais, a educação e as relações entre os sexos, esculpindo assim as interfaces do poder na convivência entre os sexos. Nesse universo, ordenadas simbolicamente, conviviam as questões ligadas à subjetividade, à 
identidade, ao sonho, à magia, às crenças e às representações. As simbologias referentes ao sexo feminino emergiam como categorizações distintas do mundo masculino, vistas como portadoras de diferenças relacionais. O olhar dominante, diga-se, masculino, no exercício das relações de poder, atribuía defeitos e qualidades nas relações de gênero. Dependendo da expectativa sobre a conduta considerada certa ou desviante, reprimia e castigava com a mesma intensidade com a qual criava um esquema de simbologias acerca da alteridade.

Não há dúvida que a religião, de qualquer origem, sempre foi decisiva na definição de padrões comportamentais femininos: o catolicismo, ao impor às mulheres a imagem da Virgem e Mãe, arquétipos sem dúvida dicotômicos; o protestantismo com seus ideais ascéticos e puritanos derivados da doutrina calvinista; o islamismo impondo às mulheres as mais pungentes humilhações e o cerceamento de liberdade individual, isso para citar apenas algumas orientações no campo do sagrado e que invocam categorias de perenidade histórica. Nesse sentido, a ideologia religiosa pode deformar a realidade ou solidificar as idéias veiculadas pela cultura, o que gera diferentes comportamentos humanos que estão ligados ao clima, às etnias, à geografia, ao desenvolvimento da economia e da política, alicerçando na sociedade um sistema de crenças e de comportamentos coletivos. Nesse sistema de crenças, a fé no mundo sobrenatural ocupa um lugar determinante nas manifestações culturais ao modelar o imaginário e instaurar comportamentos ditados por essa ideologia.

Um modelo normativo de mulheres, criado desde meados do século XIX e inspirado nos arquétipos do Cristianismo, ao espelhar a cultura vigente e instituir formas de comportamento onde se exaltavam virtudes femininas como a castidade e a abnegação, ordenava uma representação simbólica de mulher plasmada por uma ideologia imposta pela religião e pela sociedade. Nessa ideologia, o perigo era principalmente representado pela sexualidade, o que desqualificava as mulheres do ponto de vista profissional, político e intelectual ao partir do "pressuposto de que a mulher em si não é nada, de que deve esquecerse deliberadamente de si mesma e realizar-se através dos êxitos dos filhos e do marido." (RAGO, 1987, p.65). O uso de uma linguagem mística para qualificar o papel feminino também era utilizado pela ideologia, que buscava na religião as metáforas e analogias para definir a mulher-mãe com atributos de santa, anjo de bondade e pureza. Eram qualidades que todas deveriam possuir para serem dignas de coabitar com os homens e com eles gerar e criar filhos. A Igreja Católica associou a figura da mulher de família, santa e honrada, feita à imagem de Maria, à pureza de corpo e espírito, enquanto a mulher desviante, transgressora, principalmente a prostituída, foi ligada à maldade, à perfídia, ao pecado e à decadência. Se a primeira era o espírito e a santidade, a segunda era carnal e pecadora, levando os homens à corrupção do caráter e do corpo. No entanto, ambas deveriam ser submissas e dependentes, pois a ordenação social assim o exigia, e a ordem natural das coisas não deveria ser questionada por aquelas que eram as destinatárias de um processo de controle ideológico altamente repressor quanto à sexualidade. A ideia de sexo para a mulher honrada estava intimamente ligada ao corpo assexuado. A mulher não precisaria sentir prazer no intercurso sexual e de preferência deveria manter a castidade, mesmo no casamento. A forma de preservar essa castidade seria relacionar-se sexualmente apenas para a procriação, evitando-se os excessos sexuais que causariam dano à saúde e à vida espiritual feminina. $\mathrm{O}$ desejo e o prazer eram reservados aos homens, os quais, segundo o discurso médico, eram biologicamente voltados para a essência carnal por conta da virilidade. A ideologia de caráter religioso regrava, inclusive, a sexualidade do casal, devidamente sacramentado pelo ritual do casamento e perpassou a vida social do século XIX, estendendo-se ao século XX e veiculada 
na sociedade, na família e na educação. Nas escolas e cursos normais as meninas e moças, juntamente com as noções dos conteúdos educacionais, eram instruídas quanto à importância da castidade e da pureza; nas igrejas deveriam confessar aos padres quaisquer pensamentos ditos impuros; nas famílias se impedia toda e qualquer manifestação voltada para explorar ou exercer a sexualidade; na sociedade deviam comportar-se segundo as regras da moralidade. No caso de precisarem trabalhar as regras eram as mesmas, embora houvesse espaços femininos tradicionais aos quais estavam destinadas.

Do ponto de vista do trabalho feminino, vale citar Bencostta (2001, p. 123):

Com o crescimento da participação da mulher no setor de serviços, as famílias proletárias adotaram estratégias para que suas filhas não se tornassem operárias, sendo necessário, portanto, um tipo de escolarização que não ficasse restrita ao aprendizado das prendas domésticas. Carreiras como as de enfermeiras e professoras primárias, a partir de 1930, tornam-se atrativas para essas mulheres.

O autor também apresenta o conflito existente entre as regras e ordenações da Igreja Católica quanto ao trabalho das mulheres fora do lar, na mensagem do Papa Pio XII em 1945 às mulheres européias, transcrito em parte:

Aquelas dentre vós que já são esposas e mães: nos é bem conhecido quão difícil é satisfazer com fidelidade para com a Lei de Deus, os deveres de trabalhadora, em um emprego público e ao mesmo tempo os de mãe de família, como também pouco ignoramos que muitas não resistem e se rendem à tensão originada por esse duplo trabalho. Os esforços da Igreja em favor de um salário suficiente para o sustento do trabalhador e de sua família tinham e têm a finalidade de que a esposa e a mãe voltem ao seu lugar e espaço próprio. (PIO XII, 1945b, p.929; cf: BENCOSTTA, 2001, p. 122).

No magistério como ocupação feminina, a moral das professoras, em consonância com os princípios religiosos católicos e o Estado, deveria ser inatacável, naquilo que MULLER (1999), denominou "professora, vestal da Pátria". A carreira do magistério impunha regras organizativas e simbólicas que limitavam sua liberdade e expansão da autonomia pessoal e profissional; limitação aprovada também pela Sociedade da época. Cumpridoras das tarefas educacionais determinadas pelos escalões masculinos para a construção da Nação pela via da escola, as mulheres mantinham-se subordinadas à essência de um poder pouco transparente, mas bastante explícito. Ao conseguirem acesso à profissão de professoras, submeteram-se a um acréscimo na subordinação de gênero já existente: responsáveis por darem bons exemplos na adoção de uma conduta impecável na escola e fora dela, deveriam ser as virtuosas educadoras da infância; o que implicava em disciplina severa e civilizada, de acordo com os ideais que se solidificavam na edificação da nova sociedade republicana na Nação que despontava no cenário mundial.

A educação feminina e o trabalho das professoras, portanto, se referendou nas aspirações de uma sociedade católica e clerical herdada do século XIX que também influenciou os anos vindouros e o século XX, nos seus anos iniciais, seguiu os mesmos ditames e comportamentos sociais. O século XXI se abriu com várias interrogações: as diferenciações de gênero na sociedade, nas escolas, nas famílias, na religião, no mundo do trabalho serão, um dia, eliminadas? A educação de qualidade será determinante para se concretizar um futuro que o devir histórico nos mostrará? 


\section{Referências}

ALMEIDA, Jane Soares de. Ler as letras: por que educar meninas e mulheres? Campinas, Autores Associados; São Bernardo do Campo, Editora Metodista, 2007.

BENCOSTTA, Marcus Levy Albino. Mulher virtuosa, quem a achará? O discurso da Igreja acerca da educação feminina e o IV Congresso Interamericano de educação católica (1951). Revista Brasileira de História da Educação, Campinas, Autores Associados, julho/dez. 2001, n. 02 .

COOK, David. Uma sociedade pluralista. In: (vários autores). As religiões do mundo. São Paulo, Companhia das Letras, 1996.

LANE, Tony. A nova comunidade da Igreja. In: (vários autores): As religiões do mundo: do primitivismo ao século XX. São Paulo, Companhia Melhoramentos, 1996.

MULLER, Lúcia. As construtoras da nação: professoras primárias na Primeira República. Niterói, Intertexto, 1999.

RAGO, Margareth. Do cabaré ao lar: a utopia da cidade disciplinar. Brasil 1890/1930. Rio de Janeiro, Paz e Terra, 1987.

SADGROVE, Michael. Ramificações da Igreja. In: As religiões do mundo: do primitivismo ao século XX. São Paulo, Companhia Melhoramentos, (vários autores), 1996.

SOUZA, Sandra Duarte de. Violência de gênero e religião: alguns questionamentos que podem orientar a discussão sobre a elaboração de políticas públicas. São Bernardo do Campo, Mandrágora, ano XIII, n. 13, 2007.

\footnotetext{
${ }^{1}$ José Saramago no livro O Evangelho segundo Jesus Cristo desvenda um Homem, Jesus, forçado a seguir os ditames de Deus. Ao saber pelo Diabo a extensa lista dos que deveriam ser mortos, torturados e mutilados em Seu Nome, suplica: Pai, afasta de mim este cálice! Essa frase emblemática do Cristianismo revela a visão de sacrifício e renúncia que os seres humanos deveriam seguir ao professar a fé. No caso das mulheres, mais do nunca, essa foi a grande mensagem a ser seguida desde os primórdios, principalmente na religião católica.

${ }^{2}$ Como exemplo, a Inspetoria Geral da Instrução Pública da Província de São Paulo, criada em 1852, em relatório de 1870, apontava a existência de trezentas e quarenta e seis cadeiras de instrução pública para o sexo masculino; duzentas e oito cadeiras para o sexo feminino, num total de nove mil e catorze alunos e cinco mil duzentas e trinta e três alunas; cinqüenta e nove escolas particulares para ambos os sexos, com mil trezentos e vinte e um alunos; e vinte e cinco colégios de instrução secundária com oitocentos e setenta e oito alunos. (MARQUES, 1980, p.343).

${ }^{3}$ RODRIGUES (1962, p.170), relata que as primeiras escolas mistas de que se tem notícia datam de 1835 em Paranaguá e Ubatuba onde existiam classes primárias mantidas por particulares. Em 1889, em Taubaté existiam dois colégios mistos, Externato União dirigido por José ramos Ortiz e Colégio Príncipe de Nápoles de D. Elvira Colella, de origem italiana.
} 